\title{
THE EUROPEAN UNION - JAPAN STRATEGIC PARTNERSHIP IN THE CONTESTED GLOBAL ORDER. EXTERNAL RELATIONS OF THE EU IN THE CONTEXT OF ECONOMIC, NORMATIVE AND SECURITY FRAMEWORK ${ }^{1}$
}

\section{INTRODUCTION}

The global involvement of the European Union (EU) has led, over the last decades, to tailor-made approaches designed with regard to specific regions or single partner states. Their complexity seems to be growing, following the widening geographical scope of the EU's interest that started in the immediate neighborhood and ended up in remote global regions. This process is illustrated well with the example of EU-Japan relations that have developed into a form of strategic partnership. The aim of this article is to overview this partnership in the context of the changing global order, exploring its economic, normative and security dimensions. This shall lead to wider reflections allowing us to theorize international relations with regard to the concept of strategic partnerships. The research question tries to reveal what the foundations of the strategic partnership between the European Union and Japan are, and how the partnership answers the challenges in the three above indicated fields. The answer is searched for from the perspective of strategic partnership theory (Bendiek, Kramer, 2010; Biscop, Renard, 2009). Methodologically, the work is based on the analysis of primary and secondary sources (with a special focus on the representation of scholars originating from the EU, Japan and other regions) as well as on qualitative methods implemented in the form of semi-structured interviews conducted among experts in Japan in September 2019.

The paper is divided into five sections. First an overview of the development of mutual relations is provided. This is followed by testing the EU and Japan with regard to going global and describing the nature of their strategic partnership. Finally, the interpretation section allows the research questions to be answered.

1 The article was written as part of a project co-founded by the Erasmus+ Programme of the European Union "Jean Monnet Center of Excellence EU EX/ACT-EU External Actions in the contested global order - (in)coherence, (dis)continuity, resilience" (ref. 599622-EPP-1-2018-1-PL-EPPJMO$\mathrm{CoE})$.

DISCLAIMER: The European Commission support for the production of this publication does not constitute an endorsement of the contents which reflects the views only of the authors, and the Commission cannot be held responsible for any use which may be made of the information contained therein. 


\section{DEVELOPMENT OF RELATIONS BETWEEN THE EUROPEAN UNION AND JAPAN}

In the decades following the Second World War, the US formed the main direction of interest of both Japan and Western European states. Their mutual relations were of marginal relevance: Japan was focused on reconstruction, European states started to build the economic community and later the common market. Under the conditions of the Cold War and the bipolar world order, the relations practically developed only in the economic sphere. Between the 1950s and 1970s, the European Communities and Japan were involved in trade relations that determined other interactions between them. Especially when, together with the Japanese economic boom, its products appeared en masse in Western Europe. This resulted however, also in the first trade tensions (Frattolillo, 2013). The establishment of the European Communities' Common Commercial Policy in January 1970 led to the classification of Japan as the only industrialized state in Asia (Tanaka, 2013: 510). Consequently, as early as the 1970s, both sides tried to create a comprehensive trade agreement, but conflictive elements in trade relations prevented them from reaching a compromise (Tanaka, 2013: 510).

The 1980s witnessed the slow evolution of the nature of mutual relations, but it was only the 1990s that brought signals of significant change. This was caused, among other things, by the dynamic shift in the international order and led to the increasing interest of Japan in the EU, recognizing it as an international actor (Söderberg, 2014: 137; Interview 3 ). Together with the process of enlarging the EU to the East, Japanese companies started to be more and more active in this part of the continent (Bertalanič, 2018: 4-6). The 1990s were also marked by the EU's turn to Asia and the growing economic and political interest in this geographical area. Prior to the collapse of communism in (Eastern) Europe, relations were based on economic exchange, later they started changing, as manifested in the 1991 Hague Declaration (Tanaka, 2013: 509). Still, the Japanese economy has often been described as "closed" (Interview 1), and despite changes over the last two decades, foreign economic relations (as manifested by export and import) are still less visible in its economic structure(s) than in other developed states. This results especially from the economic stagnation that started in the 1990s and which diminished (together with the rise of economies of other states) the share of Japan in the global economy. The potential for intensification of foreign trade resulted in several trade agreements with partners all over the world (Hilpert, 2019: 10).

The unipolar world order of the 1990s started to be undermined at the beginning of the new millennium. At the same time, an economically booming China became an object of strategic interest for the European Union, with its cumulation in the 2000s that resulted in Japan being placed on the EU's "priority list". But in 2001, the Shaping Our Common Future: An Action Plan for EU-Japan Cooperation Action Plan was signed, and assumed the further design of ten year plans for developing mutual relations (Söderberg, 2012). Here also, the political dimension was strongly introduced: both with regard to normative as well as security elements. It was, however, critically evaluated that in the first decade following the adoption of the 2001 EU-Japan Action Plan very little was jointly implemented, especially in the fields of security and global politics. This was also recognized by both partners, with the diagnosis of a too general approach and too 
little focus on specific issues being the key problems, and with further proposals for concentrating on, among other things, conflict prevention and peace-building (Berkofsky, 2012). In the first decade of the new millennium, most of the declarations were considered as not materialized. Only at the beginning of the next decade did a visible acceleration in mutual relations become an empirical fact (Gilson, 2020).

In the 2000s, China was still seen in the EU as a partner with enormous potential for mutual benefits, while in Japan, fears about its position and behavior in the region were already strong (Załęski, Śliwa, 2019). But already in 2010 the EU-Japan summit decided to work on further agreements, strongly embedded in the context of global developments, and referring to both the economic and political fields separately, as well as other related fields (Söderberg, 2012), which very soon led to a strategic partnership. At the beginning of the $2010 \mathrm{~s}$, relations between the EU and Japan were seen as underdeveloped and having enormous potential for the future (Bacon, Kato, 2013: 82). At that time, both the Japanese elites and mass media evaluated EU-Japanese relations as important but relatively stable (and not "dynamically developing"). The EU was seen as a normative international actor, active in numerous fields and regions, very actively promoting human rights, democracy and environmental issues especially. It was perceived positively in Japan (Bacon, Kato, 2013: 81).

One of the milestones in mutual relations was the 20th European Union-Japan Summit organized on May 28, 2011 (Tanaka, 2013: 509). In the EU, together with growing disappointment about the non-economic relations with China, it was Japan that once again became a central reference point for the EU in the region. It was more and more recognized as a partner, sharing a similar approach to economic and political challenges and, in European eyes, was deemed a regional transmitter of norms and values that were central to the western normative order, especially regarding free trade, but also political freedoms and human rights (Gilson, 2020). Additionally, at the beginning of the 2010s, the EU was Japan's third biggest trade partner and Japan the seventh biggest partner of the EU (Bacon, Kato, 2013: 81). The period of the creation of the multipolar world order resulted in the mutual will to transcend the limits of economic relations and invest in both security and normative dimensions based on the closeness of strategic interests and value-oriented similarities.

Given this overview, to operationalize the investigations, a deeper look at the changing roles and perspectives of both partners seems to be necessary.

\section{CHANGING ROLES AND POLICIES}

The evolution of mutual relations between the EU and Japan was determined by the evolution of the former as an external actor, and the foreign policy changes of the latter. Both were framed by the changing global order.

\section{European Union - towards global actorness}

The case of the European Union and its external actions seems to be framed by the development of its external actorness, as well as the dominant concept of its shape. 
With regard to its actorness, the EU (with its hybrid nature, between a state and an international organization) shares competences between the community and national levels and, in international politics, acts alongside its member states. It needs to be remembered that evaluating and explaining the EU's external activities is always dependent on the specific perspective employed, which in practice means that the theoretical framework serves as an explanatory framework. Consequently, its actorness is put into question, especially from a realist angle, considering it more as a platform where state actors - member states - interact in defining common foreign interests. On the other hand, assuming, as the liberal school does, that both the common market, and peace and stability in Europe are proof of the specific enhanced relations among states, the EU seems to be a part of global governance, an additional layer in regulating international relations and shaping the global order.

The European Union's foreign policy has been operating under relatively new circumstances for the last decade, with several elements accelerating this change recently. During the Cold War, it was the US that offered a strategic umbrella over the European West; later, it still remained as the global policeman, promoting the liberal global order, sometimes using military power. The EU, hoping for the eventual worldwide dominance of the liberal order, could afford to play the role of a "normative power." Economic liberalization remained at the very core of its external activities, and the export of norms and values supplemented this approach (Lehne, 2020). The latter was visible in the fact that the EU was challenged by rapid changes in its immediate neighborhood during the collapse of communism, in the late 2000s following the Georgian war, the Arab Spring, the Ukrainian crisis and migration crisis. Changes in the global order affected it later, but maybe even more seriously, undermining not only strategies of external involvement, but also creating questions about its foundations.

But the argument about underdevelopment of the European Union's external policies is present in the literature, stressing additionally the gap between low and high politics. The self-imposed role as a civilian power additionally characterizes the EU's presence in global politics. Additionally, the fact, that both the member states and the EU are simultaneously active in international relations makes the picture even more complex. The institutional structure of the creation of external relations, with both formal and informal aspects, contributes to the problem. Altogether, it makes the EU a weak actor in the traditional vision of international relations (Milczarek, Zajączkowski, 2015). On the other hand, as Federica Mogherini pointed in the foreword to the EU Global Strategy, the "potential [of the EU] is unparalleled. Our diplomatic network runs wide and deep in all corners of the globe. [...] We are the first trading partner and the first foreign investor for almost every country in the globe. Together we invest more in development cooperation than the rest of the world combined. It is also clear, though, that we are not making full use of this potential yet. A vast majority of our citizens understands that we need to collectively take responsibility for our role in the world. [...] Our partners expect the European Union to play a major role, including as a global security provider" (Shared, 2016: 3). This statement reveals at least three elements of the new approach to the external actions of the European Union. First, it self-confidently recognizes the EU's potential, especially economic, making it one of the key global actors. Second, the fact that this position had not translated (yet) 
into a political global position. Third, this should change, as requested domestically and internationally.

The form and shape of the EU's global actorness need to be discussed as well. It seems that economic relations with third parties and their manifestation in (free) trade agreements seemed to dominate the EU's external involvement. This was, on the one hand, politically insufficient, on the other, the approach experienced several spectacular failures, as manifested for example by the resignation from further negotiations on the Transatlantic Trade and Investment Partnership (TTIP) (Grübler, Reiter, Stehrer, 2019: 17).

It was, however, the concept of normative or civilian power that was undertaken and implemented most intensively by the EU externally over decades. It stresses norms and values as dominant over interests when creating international activities. It has been assumed additionally that the normative foundations of the EU are attractive enough to attract other states. On the other hand, their active promotion has been proposed to contribute to shaping not only its own neighborhood but also the wider, global order. If the international order could be de- or reconstructed, it could also be further constructed.

The changing global environment and the EU's growing global involvement resulted in a security-oriented modification. The new rhetoric of power, geopolitics and strategy in international policy appeared among leaders of the EU in late 2019, which was especially surprising, because the whole integration concept had been based on proposing alternative ideas (Lehne, 2020). It was claimed that the EU should still rely on soft power, but "the idea that Europe is an exclusively 'civilian power' does not do justice to an evolving reality" (Shared, 2016: 3). As Stefan Lehne points out, the changing international environment is affecting the field the EU plays in, especially with regard to the three main actors shaping it: Russia, China and the USA (Lehne, 2020). Putin's Russia has been constantly moving away from the western norm, both in domestic politics (visible in growing authoritarianism), as well as international politics (as manifested in the Ukrainian crisis). China has been following a model of economic growth that is not accompanied by political change; moreover, its growing economic potential translates into growing global aspirations. The US, under Trump's presidency, proposed an egoistic trade policy and revealed a much more confrontational foreign policy, even undermining transatlantic ties. All those things resulted in an already visible "strategic shift" in the EU vision of external relations. The approach dominating before the EU's 2016 Global Strategy stressed a conditionality mechanism leading to the political, economic and normative transformation of neighboring spaces. The changing international environment, and failure of this approach, led to a new vision, stressing stability, resilience and EU interests, all of them in the global dimension (Lehne, 2020: 3). The EU's Global Strategy recognizes the changing nature of the international environment the Union is operating in. It refers both to the immediate neighborhood, as well as remote regions and global processes (Shared, 2016: 3). The consequences of the current development within the EU, especially related to Brexit remains an open question (Niblett, 2019). At the same time, however, postulates of a stronger profile in global politics recognize the fact that the EU lacks capabilities with regard to traditional power in international politics (because of the lack of mili- 
tary power and differences in member states' positions) but it can effectively use its economic position in foreign policy (with more coherence and the leading position of Brussels). And, as Stefan Lehne claims, "the Union needs to understand the risks of taking on a geopolitical role and enhance its resilience and autonomy while continuing to work toward a rules-based multilateral order" (Lehne, 2020: 1).

\section{Japan - towards multilateralism}

The changing global order has resulted, in the case of Japan, in two long-lasting tendencies: first, concentrating on economic relations as key instrument of achieving political goals, step by step supplemented by strategic and normative components, and second, growing proactivity resulting in regional, and then global involvement.

With regard to the former, it seems to be important to stress that post-1945 Japanese foreign policy was based on the United Nations, cooperation with free states and Asian identity. In the 21st century, this was supplemented with the two concepts of the East Asian Community and the Arc of Freedom and Prosperity (Hosoya, 2013). The Japanese Yoshida Doctrine, rooted in realism, stressing economic development and assuming that the alliance with the US is the basis of this state's security, was challenged, together with the modification of American foreign policy after 2017. Some research has claimed, however, that the slow distancing from it has recently been visible (Kallender, Hughes, 2019). Nori Katagiri claims, when describing Shinzo Abe's Indo-Pacific Strategy, that the combination of defensive realism (regarding security policy) and liberalism (employing economic instruments) best explains the Japanese concentration on the economic aspect of regional partnerships. This results in an active policy of building strategic partnerships and economic networks in Southeast Asia (Katagiri, 2019). This approach has been supplemented, among others, in the Free and Open Indo-Pacific concept, which started with building a cooperative network between democratic states present in the region, and ended up with including China in the set of interdependences (Hosoya, 2019). This includes Japanese involvement in economic development in numerous regions of South-East Asia (that has been marked since the 1990s) but also the search for political dialog and "building an East Asian order based on 'universal values' such as democracy and the rule of law" (Ogasawara, 2015: 34). At the same time "Japan and China have engaged in seikei bunri (separation of politics and economics) relations to mutually benefit each other's economic development" (Nagy, 2015: 5).

At the same time, the last decade resulted in growing instability in East Asia, visible from the Japanese perspective especially in US-China competition, but also Chinese territorial claims in the South and East China Seas, and the aggressive policy of North Korea (Hosoya, 2015a). Donald Trump's global policy was also considered to have had a significant impact on the security of Japan and of being one of the factors pushing the latter to a more proactive foreign policy (Schoff, 2018).

More proactive and strategically oriented elements in Japanese foreign policy started to be visible together with the first government of Shinzo Abe, with his flagship initiative of the Arc of Freedom and Prosperity. This approach was extended to relations 
with the EU (Bertalanič, 2018: 7, 9). In the 2000s, Japan became very vocal internationally with regard to the normative dimension of international politics, with a special focus on democracy promotion, rule of law, and the principle of multilateralism (Hosoya, 2012: 317). New security legislation passed in 2015 reflected the changing Japanese position towards new challenges in East Asia (Hosoya, 2015). It "has identified the need for itself and others to be an important player in the region as a constructive alternative to Chinese geostrategic dominance in various domains" (Wallace, 2013: 509), looking even for regional leadership (Sahashi, Gannon, 2017). Japan has also been actively collaborating with NATO, including assistance in Afghanistan's reconstruction, and anti-piracy measures in the Indian Ocean and in the Gulf of Aden (Patalano, 2016). One of the key principles of the Japanese National Security Strategy is "proactive contribution to peace" (Kitaoka, 2014). But Japan also cooperated closely with other partners, including Australia (Strategic Partnership in Capacity Building for Maritime Security, see: de Castro, 2017), India (Mukherjee, Yazaki, 2016), or Vietnam (Do, 2014). Broad-based multilateralism is one of the key features of Abe's "proactive pacifism," with trade agreements being its main tool, as well as active involvement in international organizations and security operations at the regional level (Nagy, 2017). The Japanese concept of a "proactive contribution to peace" in international politics tries to merge its (self)image of a peace-oriented nation and the necessity of spreading stability (Hosoya, 2015b). Japanese Silk Road Diplomacy has been addressing Central Asian states with both economic, but also political and normative aims. Soft power has been used specifically, as manifested by educational investments and projects, as well as humanitarian aid (Dadabaev, 2017: 5-8).

\section{STRATEGIC PARTNERSHIP}

The strategic partnership relations between the EU and Japan have developed in the context of European-East Asian mutual prioritization and materialized in the form of a gradual shift from the economic to the normative and security dimensions.

The EU intensified its activity in East and South-East Asia around the 2010s, as reflected in intensive bilateral visits and participation in summits of regional organizations (Reiterer, 2018: 50). As the official documents of the EU stated, "Asia, with roughly $60 \%$ of the world population accounts for $35 \%$ of the EU's exports ( $€ 618 \mathrm{bn}$ ) and $45 \%$ of the EU's imports ( $€ 774 \mathrm{bn})$ " which is a chance for both sides "for increased cooperation, for peaceful political cooperation, fair and stronger economic relations, comprehensive societal dialogue and collaboration on international and regional security. Europe and Asia, together, can be the engines of a more cooperative approach to world politics, global stability and regional economic prosperity" (Connecting, 2018). Economic ties have been seen, consequently, as a driving force for non-economic purposes.

The EU's Strategy on Connecting Europe and Asia presented during the 12th AsiaEurope Meeting (ASEM) in October 2018 tried to merge the great infrastructural projects of the Asian partners with trans-European infrastructural networks by stressing interoperable transport, energy and digital networks, but also proposing a new ap- 
proach to social and environmental issues. It emphasized "sustainable, comprehensive and rule-based connectivity" (Connecting, 2018) following the general approach of norm- and value-based international involvement. In line with this approach, special focus was also placed on people-to-people connectivity, materializing in proposals strengthening exchange programs for students and academics. The document proposes a tailor-made approach for different states. In the case of China, its focus is to strengthen "existing cooperation on the respective infrastructure and development cooperation initiatives, promote the implementation of the principles of market access [...], as well as rely on international standards within initiatives on connectivity." In the case of Japan, the focus was on coordination of "efforts to promote international standards and regional cooperation in Asia" (Connecting, 2018).

China was the fulcrum in intercontinental relations, with changing approaches of stakeholders over time. Especially recently, the EU seems to be divided with regard to how to organize trade relations with China, as exemplified by the $17+1$ forum or its reaction to the Belt and Road Initiative (with the center and east of the continent being more enthusiastic). On the other hand, the Connectivity Strategy for Asia (Connecting, 2018) seems to be the European response to the challenge, with Japan playing a crucial role there. Connectivity concentrates on both values and interests. A forum was organized on September 27, 2019, with the Japanese Prime Minister Shinzo Abe being the key speaker.

In this context, the EU and Japan have undergone several stages in their mutual relations, shaping what nowadays is considered a strategic partnership. This, despite the fact that the origins of these contacts were not very promising. Also, the later evaluation of EU-Japanese relations was often marked by a critical approach with regard to using existing potential. This disappointment pointed at declarations and possibilities that had not been used (Masujima, 2015: 584). The 2010s brought an intensification of EU-Japan cooperation with regard to global peace and stability, and responding to global challenges, with a tendency to employ multilateral platforms (Sabathil, 2015). But, as Julie Gilson claims, the origins of both the Economic Partnership Agreement and the Strategic Partnership Agreement are rooted in the changing global order with regard to economy and security, as illustrated especially by the numerous free trade agreements and the role played by the US in global politics (Gilson, 2020).

As already stressed, for decades EU-Japan relations were marked by a mainly economic flavor (Defraigne, Hiromasa, Christiansen, 2018).

Strategic partnership agreement negotiations were held between March 2013 and December 2017 and contained 18 rounds. The economic partnership eventually materialized on February 1, 2019, when the Economic Partnership Agreement (EPA) went live. Its quantitative consequences were impressive at first glance: it covered the space of almost one third of global GDP and almost 640 million inhabitants. Japan eliminated $97 \%$ of tariffs previously charged on imports from the EU (referring to $99 \%$ of important products) (Gilson, 2020).

The EPA also included agricultural produce, considered the most difficult items in global trade agreements, which potentially gave access to most EU products to the Japanese market without being charged duty (Grübler, Reiter, Stehrer, 2019: 17). It also introduced relevant provisions related to sustainable development, climate protec- 
tion and labor rights (Gilson, 2020). The EPA could also be seen as a strong message of non-acceptance of protectionism and trust in a rule-based economic global economic order that was addressed especially to the US (Grübler, Reiter, Stehrer, 2019: 24).

As Hitoshi Suzuki points, the EPA with Japan has not been the object of broad criticism in Europe, as happened with similar agreements negotiated with other partners, especially with the US. He sees the reason for this in the "traditional" character of the deal, concentrating on the elimination of tariffs and the dominant position of the EU in rule promotion (Suzuki, 2017). Claes G. Alvstam and Erja Kettunen claim that the EU-Japan EPA "was the result of one of the most swiftly negotiated bilateral trade agreements since the European Union launched its 'Global Europe' initiative in 2006" (Alvstam, Kettunen, 2019: 3).

The EPA was expected in the EU to have significant political and normative consequences. It was assumed that the economic "cooperation will enhance the ability of both parties to shape the course of global developments in a manner that better reflects their shared interests and values, such as their commitment to a rule-based global trade system and the fight against global warming" (The EU-Japan, 2018: 2). Both the EU and Japan are considered to be protectors of multilateralism and rule-based global trade relations (Defraigne, Hiromasa, Christiansen, 2018). Economic benefits resulting from the elimination of trade barriers were considered just a part of the agreement. It was aimed that "the EPA will boost the EU's economic presence and political relevance in the Asia-Pacific area" (The EU-Japan, 2018: 2). Finally, it reflected all three of the main principles of Japanese policy towards the EU, containing economic partnership, peace and stability and a joint approach to the promotion of global challenges (Reiterer, 2018: 51).

On February 1, 2019 the Strategic Partnership Agreement (SPA) also came into force. This was conditional on its expected ratification. Its main provisions refer to political aspects of cooperation between the EU and Japan (Gilson, 2020). Daniel Fiott claims that the SPA, "is not just a way of enhancing political dialogue since it also acts as a binding security pact that allows the EU and Japan to address common global interests and security issues" (Fiott, 2018: 41). Employing the perspective of realism, the EU and Japan have been missing a strategic security dimension similar to relations between Japan and the US. On the other hand, however, already during the Cold War, a dialog was initiated, concentrating on low politics (Mykal, 2011: 19-60). The 1991 Hague Declaration brought a new dimension into the security debate between the partners. The following years covered the areas of environment, science, technology and energy (Mykal, 2011). When looking for an explanation, similarities in the political and geopolitical situations of the EU and Japan can be enumerated, including the neighborhood of strong states undermining the existing balance of power and rules of international order (respectively Russia and China), or the redefinition of the relations with the US (Fiott, 2018: 41).

On the one hand, the SPA is a way for the EU to promote its role as a security broker in East Asia, still acting as a normative, not a military power (Fiott, 2018: 41). On the other, despite the role of normative power played by both the EU and Japan, they have been developing military capabilities over the last years (Fiott, 2018: 42). As Lisa Picheny remarks, "both NATO and Japanese leaders refer to the notion of "natural 
partners', highlighting Japan's status as the Alliance's 'longest-standing partner across the globe'. These statements reflect what both sides see as the fundamental tenet of the relationship: a sense of certainty and durability, anchored in active political dialogue since the 1990s" (Picheny, 2018: 37). Over the years Japan has cooperated with the EU, among others, in Mali, Niger and in the anti-piracy missions on the African east coast (Fiott, 2018: 41).

Normative proximity has its limitations. On the one hand, the EU and Japan tend to promote similar norms and values. On the other, however, there are areas of normative differences, and the death penalty represents one such case. The EU has been constantly pressing Japan with regard to abolishing this punishment (Interview 2).

Trying to evaluate the strategic partnership, a huge development can be observed in mutual relations. The 2001 Action Plan was criticized for being too general and not focus-oriented enough. Including numerous areas of cooperation, it lacked not only coherence but also specific tools of implementation. Additionally, the more pressing economic issues (especially in the context of economic crisis) pushed the normative and non-economic aspects aside (Gilson, 2020). Michael Reiterer pointed out that, already during the 2015 EU-Japan summit, both sides agreed that "the FTA and the SPA will be the centerpiece for the future, as they would not only strengthen bilateral ties by giving the relationship direction and purpose but also contribute to the formation of rules of global governance, especially through agreements on standards" (Reiterer, 2018: 51). Julie Gilson interprets the EU-Japan partnership as an example of how both "behave as global actors [...] [and] how the democratic states face a contemporary assault on the liberal free-trading order and Western concepts of rights-based international relations" (Gilson, 2020). Daniel Fiott points out that "currently, the EU and Japan's relationship must be seen through the prism of the EPA and SPA. In this respect, there may be room for the EU and Japan to not only support multilateralism and a liberal international order but also to focus on practical security issues" (Fiott, 2018: 44).

\section{INTERPRETATION AND CONCLUSIONS}

This text has aimed at answering the question of the foundations of the strategic partnership between the European Union and Japan. Interpreting the empirical part within the context of the literature, trying to theorize the concept of strategic partnership, several interesting conclusions can be presented. The economic approach to studying strategic alliances stresses the role of resources that are mutually useful as the key factor behind close cooperation (Das, Teng, 2000). Razvan-Alexandru Gentimir claims (after Biscop, Renard, 2009) that "there are a few pre-established criteria when choosing the partners, beyond the common values and objectives sharing [sic]. Partners should be though [sic] capable of having some influence in global or regional problems" (Gentimir, 2015: 290). Finally, Lucyna Czechowska indicates seven criteria constituting strategic partnership, including: partnership position, similarity of goals of partners, shared believed in joint actions, real cooperation in achieving them, abovenormal intensity of contacts, high level of institutionalization of relations and, positive "atmosphere" resulting in "warm feelings" (Czechowska, 2013: 51). The above 
presented investigation proves that at least the first six of them have been fulfilled over the last decades.

With regard to the question of how the strategic partnership answers the challenges in the fields of economic cooperation, normative proximity and the security dimension, it can be stressed that an approach of gradually moving from the economic to political dimension can be observed. The EU's growing global actorness and involvement results in confrontation with other regional groupings and, more generally, in regionalism. This is also the case in East Asia (Shu, 2015). Yuichi Hosoya claims that between 1991 and 2011, "while endeavoring to expand its economic ties with China, the EU also attempts to be a 'normative power', but, because of the limited nature of the EU's influence in East Asia, it needs normative partners in this region [...] the EU-Japan relationship is becoming more vital because of the increasing importance of norms due to the rise of China" (Hosoya, 2012). The EU's Global Strategy recognizes "security tensions in Asia" (Shared, 2016: 7). Consequently, a shift from the economic focus to a multidimensional and strategic approach has been visible over the decades in mutual relations (Reiterer, 2018: 51). What is probably of key relevance to understand the relations between the EU and Japan, recent decades have been marked by an orientation toward economic cooperation gradually being supplemented by political dialog, while non-economic components have been present in mutual contacts and negotiations. Non-economic aspects of mutual relations included several fields. Counter-terrorism was introduced by the Joint Declaration in 2001 (resulting, among other things, from the new situation after the New York attacks) and consequently present during annual summits. Climate change related cooperation intensified, especially after the 1997 Kyoto Protocol (revealing the leading role taken by the EU, the involvement of Japan and similar position of both to strengthen the UN format for environmental challenges). The cooperation in the field of human security has been visible since the beginning of the 2000s (Gilson, 2020). Both sides have strongly supported a multilateral approach to dealing with global challenges and a commitment to structures framing multilateral cooperation, especially the United Nations. Promotion of a rule-based global order is stressed both by the EU (Shared, 2016: 8) and Japan, especially as the EU is a regional power, but not a global leader (Fröhlich, 2014; Harnisch, 2011). Japan, as Faizullah Khilji claims, tries to lead "a regional order defined by a diamond of security and democracy, a latter-day version of the empires of old. The path that Mr Abe seems to chart towards this goal lies via [sic] enhancing Japan's military capabilities and via military alliances that seek freedom of the seas but also avowedly seek to set limits to China" (Khilji, 2015: 440).

\section{REFERENCES}

Alvstam C. G., Kettunen E. (2019), The EU-Japan Economic Partnership Agreement: Second Best Option or New Generation of Preferential Trade Arrangements?, „CESifo Forum”, Vol. 20, No. 2.

Bacon P., Kato E. (2013), Potential Still Untapped: Japanese Perceptions of the European Union as an Economic and Normative Power, „Baltic Journal of European Studies”, Vol. 3, No. 3 (15). 
Bendiek A., Kramer H. (2010), The EU as a 'Strategic'International Actor: Substantial and Analytical Ambiguities, „European Foreign Affairs Review”, Vol. 15, Issue 4.

Berkofsky A. (2012), EU-Japan relations from 2001 to today: achievements, failures and prospects, „Japan Forum”, Vol. 24, No. 3, https://doi.org/10.1080/09555803.2012.699453.

Bertalanič B. (2018), Opportunities and Challenges for V4 plus Japan Relations in the Post-Brexit $E U$, ,Electronic Journal of Central European Studies in Japan”, No. 4.

Biscop S., Renard T. (2009), The EU's strategic partnerships with the BRIC: Where's the Strategy?, „BEPA Monthly Brief”, No. 29.

Connecting Europe and Asia - Building Blocks for an EU Strategy, Communication to the European Parliament, the Council, the European Economic And Social Committee, the Committee of the Regions and the European Investment Bank, Brussels, 19.9.2018 JOIN(2018) 31, High Representative of the Union for Foreign Affairs and Security Policy.

Czechowska L. (2013), The Concept of Strategic Partnership as an Input in the Modern Alliance Theory, „The Copernicus Journal of Political Studies”, No. 2(4).

Dadabaev T. (2017), "Silk Road" as foreign policy discourse: The construction of Chinese, Japanese and Korean engagement strategies in Central Asia, „Journal of Eurasian Studies”, Vol. 9, https://doi.org/10.1016/j.euras.2017.12.003.

Das T. K., Teng B.-S. (2000), A resource-based theory of strategic alliances, „Journal of Management", Vol. 26, Issue 1, https://doi.org/10.1016/S0149-2063(99)00037-9.

De Castro R. C. (2017), The Special Japan-Australia Strategic Partnership within the ambit of Democratic Security Diamond: Seeking Partnership with Philippines in Maritime Security, Manila.

Defraigne J.-C., Hiromasa K., Christiansen T., et. al. (2018), The Economic Security Dimension in EU-Japan Relations, in: EU-Japan Security Cooperation: Trends and Prospects, (eds.) E. J. Kirchner, H. Dorussen, London.

Do T. T. (2014), Locating Vietnam-Japan's Strategic Partnership In The Changing East Asian Political Landscape, "JIIA Paper".

Fiott D. (2018), A New Dynamic in EU-Japan Relations, in: Natural partners? Europe, Japan and security in the Indo-Pacific, (eds.) L. Simón, U. Speck, Madrid.

Frattolillo O. (2013), Diplomacy in EU-Japan Relations: from the Cold War to the post-bipolar era, London-New York.

Fröhlich S. (2014), Die Europäische Union als globaler Akteur, Wiesbaden.

Gentimir R.-A. (2015), A Theoretical Approach on the Strategic Partnership Between the European Union and the Russian Federation, „CES Working Papers”, Vol. 7, Issue 2.

Gilson J. (2020), EU-Japan Relations and the Crisis of Multilateralism, New York.

Grübler J., Reiter O., Stehrer R. (2019), The EU-Japan EPA: A Case for Non-tariff Measures, „CESifo Forum”, Vol. 20, No. 2.

Harnisch S. (2011), Role theory in international relations, London.

Hilpert H. G. (2019), The Japan-EU Economic Partnership Agreement: Opportunities and Pitfalls, „CESifo Forum”, Vol. 20, No. 2.

Hosoya Y. (2012), The evolution of the EU-Japan relationship: towards a 'normative partnership'?, „Japan Forum”, Vol. 24, No. 3, https://doi.org/10.1080/09555803.2012.699455.

Hosoya Y. (2013), Japan's Two Strategies for East Asia: The Evolution of Japan's Diplomatic Strategy, „Asia-Pacific Review”, Vol. 20, No. 2, https://doi.org/10.1080/13439006.2013.863825.

Hosoya Y. (2015a), Japan's New Security Legislation: What Does This Mean to East Asian Security?, „American Foreign Policy Interests”, Vol. 37, No. 5-6, https://doi.org/10.1080/10803920.2 016.1162070 . 
Hosoya Y. (2015b), Historical Memories and Security Legislation: Japan's Security Policy under the Abe Administration, „Asia-Pacific Review”, Vol. 22, No. 2, https://doi.org/10.1080/134390 06.2015.1123133.

Hosoya Y. (2019), FOIP 2.0: The Evolution of Japan's Free and Open Indo-Pacific Strategy, „AsiaPacific Review", Vol. 26, No. 1, https://doi.org/10.1080/13439006.2019.1622868.

Interview 1, 19.11.2019, EU-Japan Center for Industrial Cooperation, Tokyo, Japan.

Interview 2, 19.11.2019, The EU Studies Association, Faculty of Law, Sophia University, Tokyo, Japan.

Interview 3, 21.11.2019, European Policy Division, European Affairs Bureau, Ministry of Foreign Affairs, Tokyo, Japan.

Kallender P., Hughes C. W. (2019), Hiding in Plain Sight? Japan's Militarization of Space and Challenges to the Yoshida Doctrine, „Asian Security”, Vol. 15, No. 2, https://doi.org/10.1080/14 799855.2018 .1439017$.

Katagiri N. (2019), Shinzo Abe's Indo-Pacific Strategy: Japan's recent achievement and future direction, „Asian Security”, Published online: 16 May, https://doi.org/10.1080/14799855.2019.1 607304.

Khilji F. (2015), Whither Mr Abe's Japan?, „Asian Affairs”, Vol. 46, No. 3, https://doi.org/10.1080/ 03068374.2015.1080998.

Kitaoka S. (2014), A "Proactive Contribution to Peace" and the Right of Collective Self-Defense: The Development of Security Policy in the Abe Administration, „Asia-Pacific Review”, Vol. 21, No. 2, https://doi.org/10.1080/13439006.2014.985237.

Kusune S. (2016), The relationship between Japan and the EU, „Journal of Global Tourism Research", Vol. 1, No. 2.

Lehne S. (2020), How the EU Can Survive in a Geopolitical Age, „Carnegie Europe”, 25.02.2020.

Masujima K. (2015), EU-Japan Relations, in: The SAGE Handbook of European Foreign Policy, (eds.) K. E. Jorgensen, K. Aarstad, E. Drieskens, K. Laatikainen, B. Tonra, Los AngelesLondon-Washington DC-New Delhi-Singapore.

Milczarek D., Zajączkowski K. (2015b), Potęga i niemoc. Unia Europejska jako aktor w stosunkach międzynarodowych (część 2), „Studia Europejskie”, No. 1.

Mukherjee R., Yazaki A. (eds.) (2016), Poised for Partnership Deepening India-Japan Relations in the Asian Century, Oxford.

Mykal O. (2011), The EU-Japan Security Dialogue: Invisible but Comprehensive, Amsterdam.

Nagy S. R. (2015), Balancing Trade and Security Relationships in the Asia Pacific: The Advent of a Trilateral Seikei Bunri Relationship between Japan, China, and the U.S., ,Journal of Asian Politics \& History", No. 6.

Nagy S. R. (2017), Japan's Proactive Pacifism: Investing in Multilateralization and Omnidirectional Hedging, „Strategic Analysis”, Vol. 41, No. 3, https://doi.org/10.1080/09700161.2017.1295 607.

Niblett R. (2019), Prospects for the UK and Japan as International Actors and Partners, in: The UK and Japan Forging a Global and Proactive Partnership, (eds.) J. Nilsson-Wright, London.

Ogasawara T. (2015), Development of the Mekong Region as Part of Japan's Diplomatic Strategy for East Asia, „Asia-Pacific Review”, Vol. 22, No. 1, https://doi.org/10.1080/13439006.201 5.1038889 .

Patalano A. (2016), 'Natural Partners' in Challenging Waters?, „The RUSI Journal”, Vol. 161, No. 3 , https://doi.org/10.1080/03071847.2016.1193356. 
Picheny L. (2018), A growing partnership between NATO and Japan, in: Natural partners? Europe, Japan and security in the Indo-Pacific, (eds.) L. Simón, U. Speck, Madrid.

Reiterer M. (2018), The EU's security interests in East Asia. Japan as a strategic Partner, in: Developing EU-Japan Relations in a Changing Regional Context: A Focus on Security, Law and Politics, (eds.) D. Vanoverbeke, T. Suami, T. Ueta, N. Peeters, F. Ponjaert, New York.

Sabathil G. (2015), Making the Strategic Partnership between Japan and Europe Work, „Asia-Pacific Review", Vol. 22, No. 2, https://doi.org/10.1080/13439006.2015.1109168.

Sahashi R., Gannon J. (eds.) (2015), Looking for Leadership: The Dilemma of Political Leadership in Japan, Tokyo.

Schoff J. L. (2018), Political Change in America and Implications for the US-Japan Alliance, „AsiaPacific Review", Vol. 25, No. 2, https://doi.org/10.1080/13439006.2018.1545489.

Shared Vision, Common Action: A Stronger Europe. A Global Strategy for the European Union's Foreign And Security Policy, June 2016.

Shu M. (2015), The EU and Economic Regionalism in East Asia, in: Interregionalism and the European Union. A Post-Revisionist Approach to Europe's Place in a Changing World, (eds.) M. Telò, L. Fawcett, F. Ponjaert, London.

Söderberg M. (2012), Introduction: where is the EU-Japan relationship heading?, „Japan Forum”, Vol. 24, No. 3, https://doi.org/10.1080/09555803.2012.699452.

Söderberg M. (2014), Understanding the EU-Japan Relationship: A Basis for Interpreting the Future, „The International Spectator”, Vol. 49, No. 2.

Suzuki H. (2017), The new politics of trade: EU-Japan, „Journal of European Integration”, Vol. 39, No. 7, https://doi.org/10.1080/07036337.2017.1371709.

Tanaka T. (2013), EU-Japan Relations, in: The Palgrave Handbook of EU-Asia Relations, (eds.) T.Christiansen, E. Kirchner, P. Murray, London.

The EU-Japan Economic Partnership Agreement (2018), Study Requested by the INTA committee, Policy Department for External Relations Directorate General for External Policies of the Union, PE 603.880 - September 2018, European Parliament.

Wallace C. J. (2013), Japan's strategic pivot south: diversifying the dual hedge, „International Relations of the Asia-Pacific", Vol. 13, https://doi.org/10.1093/irap/lct011.

Załęski K., Śliwa Z. (2019), China-Japan Inlands Disputes as the Challenge in Evolving Security Environment, „Security Forum”, Vol. 3, No. 2.

\begin{abstract}
The aim of this article is to review the strategic partnership of the European Union-Japan in the context of the changing global order, exploring economic, normative and security dimensions. This leads to wider reflections allowing us to theorize international relations with regards to the concept of strategic partnerships. The research question concentrates on what the foundations of the strategic partnership between the European Union and Japan are, and how it answers the challenges in the three above indicated fields. The hypothesis is formulated from the perspective of strategic partnership theory. Methodologically, the work is based on the analysis of primary and secondary sources, as well as on qualitative methods implemented in the form of semi-structured interviews. The key findings reveal that the changing global order and international environment have pushed both partners to create a strategic partnership that has spilled over from economic relations to the normative, political and finally security fields.
\end{abstract}

Keywords: strategic partnership, European Union, Japan, external activities of the EU 


\section{PARTNERSTWO STRATEGICZNE UNII EUROPEJSKIEJ W ZMIENIAJĄCYM SIĘ PORZĄDKU MIĘDZYNARODOWYM. STOSUNKI ZEWNĘTRZNE UE W KONTEKŚCIE UWARUNKOWAŃ GOSPODARCZYCH, NORMATYWNYCH I BEZPIECZEŃSTWA}

\section{STRESZCZENIE}

Celem artykułu jest analiza partnerstwa strategicznego Unia Europejska-Japonia w kontekście zmieniającego się porządku globalnego oraz zbadanie jego wymiarów ekonomicznego, normatywnego i dotyczącego bezpieczeństwa. Prowadzi to do szeregu refleksji umożliwiających teoretyzowanie stosunków międzynarodowych w odniesieniu do koncepcji partnerstwa strategicznego. Pytania badawcze koncentrują się wokół fundamentów specjalnych relacji między Unią Europejską i Japonią, i kwestii jak odpowiada ono wyzwaniom w trzech wskazanych powyżej obszarach. Hipotezy sformułowane zostały z perspektywy teorii partnerstwa strategicznego. Metodologicznie praca opiera się na analizach źródeł pierwotnych i wtórnych oraz metodach jakościowych realizowanych w formie semiustrukturyzowanych wywiadów. Kluczowe wnioski pokazują, że zmieniający się porządek globalny i otoczenie międzynarodowe zmusiły obu partnerów do tworzenia strategicznego partnerstwa, które przenosi się ze stosunków gospodarczych na obszary normatywne, polityczne i wreszcie do obszaru bezpieczeństwa.

Słowa kluczowe: partnerstwo strategiczne, Unia Europejska, Japonia, aktywności zewnętrzne UE 
